Setting Alexandria Police Hospital.

Results $86 \%$ of patients with bronchial asthma lived in urban areas, while $64 \%$ of patients with parasitic infestation lived in rural areas. Statistically significantly Negative correlations were found between blood level of IgE and FEV1\% of predicted in patients with bronchial asthma as well as patients with parasitic infestation with $\mathrm{r}=-0.381,-0.325$ at $\mathrm{p}=0.006,0.021$ respectively. Inverse relationship was found between blood level of IgE and $\mathrm{FEV} 1 / \mathrm{FVC} \%$ in patients with parasitic infestation with $r=-0.358$ with statistical significant difference at $p=0.011$.

Conclusions Statistically significance higher values of $\operatorname{IgE}$ were found in patients with parasitic infestation compared to patients with bronchial asthma. It was noted that patients with combined bronchial asthma and parasitic infestation demonstrated statistically significance higher values of IgE which suggest a possible synergistic effect of two diseases.

Recommendation Improving personal and environmental hygiene and regular screening, treatment and health education for children as regard parasitic infections is recommended.

\begin{tabular}{|l|c|c|c|c|c|}
\hline & $\begin{array}{c}\text { Asthmatic } \\
(\mathbf{n}=\mathbf{4 8})\end{array}$ & $\begin{array}{c}\text { Parasitic } \\
(\mathbf{n}=\mathbf{4 7})\end{array}$ & $\begin{array}{c}\text { Combined } \\
(\mathbf{n}=\mathbf{5})\end{array}$ & KW & $\mathbf{p}$ \\
\hline IgE & & & & & \\
$\begin{array}{l}\text { Min. }- \\
\text { Max. }\end{array}$ & $100.0-490.0$ & $122.0-900.0$ & $850.0-1003.0$ & & \\
$\begin{array}{l}\text { Mean } \pm \\
\text { SD. }\end{array}$ & $\begin{array}{c}258.35 \pm 106 . \\
58\end{array}$ & $\begin{array}{c}400.79 \pm 196.7 \\
9\end{array}$ & $938.40 \pm 63.56$ & 26.302 & $<0.001$ \\
Median & 247.0 & 344.0 & 950.0 & & \\
\hline $\begin{array}{c}\text { Sig. Bet. } \\
\text { Grps. }\end{array}$ & \multicolumn{2}{|c|}{$\mathrm{p}_{1}<0.001^{*}, \mathrm{p}_{2}<0.001^{*}, \mathrm{p}_{3}<0.001^{*}$} & & \\
\hline
\end{tabular}

KW: Kruskal Wallis test, Sig. bet. grps was done using Mann Whitney test

$\mathrm{p}_{1}$ : $\mathrm{p}$ value for comparing between asthmatic and parasitic group

$\mathrm{p}_{2}$ : $\mathrm{p}$ value for comparing between asthmatic and combined group

$\mathrm{p}_{3}$ : $\mathrm{p}$ value for comparing between parasitic and combined group

*: Statistically significant at $\mathrm{p} \leq 0.05$.

Abstract P70 Figure 1 Comparison between the three groups according to IgE.

\section{P71 MEPOLIZUMAB IN ADOLESCENTS WITH SEVERE EOSINOPHILIC ASTHMA NOT ELIGIBLE FOR OMALIZUMAB: ONE CENTRE'S EXPERIENCE}

${ }^{1}$ E Weir, ${ }^{2}$ JY Paton. ${ }^{1}$ Royal Hospital for Children, Glasgow, UK; ${ }^{2}$ School of Medicine, College of Medical, Veterinary and Life Sciences, University of Glasgow, Glasgow, UK

\subsection{6/thoraxinl-2017-210983.213}

Introduction Mepolizumab is an anti-interleukin-5 monoclonal antibody shown to reduce asthma exacerbations in adults and adolescents with severe eosinophilic asthma. ${ }^{1}$ The Scottish Medicines Commission has accepted it for restricted use in adults as an add-on treatment for severe refractory eosinophilic asthma. Here we describe the use of Mepolizumab as an unlicensed medicine with local approval for use in adolescents with severe asthma.
Methods Mepolizumab was offered to adolescents with severe eosinophilic asthma not eligible for Omalizumab because of previous allergic reaction $(n=2)$ or failure to respond $(n=1)$ to Omalizumab, or excessively high $\operatorname{IgE}(n=4)$. Eosinophilic asthma was confirmed: blood eosinophil count $\geq 300$ cells $/ \mu \mathrm{L}$ or exhaled nitric oxide concentration (FeNO) $\geq 50 \mathrm{ppb}$ in the previous year. All received high-dose ICS + LABA and had low ACT scores (mean 10.4 \pm 2.88 ). Four were on daily oral steroids. Mean exacerbations requiring oral steroids in the previous year were $4.9 \pm 1.68$. Prior to commencing and before each monthly injection, pulmonary function (FeNO and forced expiratory volume in $\left.1 \mathrm{~s}\left(\mathrm{FEV}_{1}\right)\right)$, blood eosinophil count, Asthma Control Test (ACT) and Paediatric Asthma Quality of Life Questionnaire (PAQLQ) were measured. Long-term medications not adjusted. Data from clinical case notes.

Results Seven adolescents (mean age 13.9 \pm 1.9 , range 11-17 years; 5 males, 2 females) each received 4 Mepolizumab doses (100 mg sc) at monthly intervals with no serious adverse reactions. Blood eosinophil count decreased in all (mean pre-treatment $0.8 \pm 0.62 \times 10^{9}$ cells $/ \mathrm{L}, 0.1 \pm 0.06 \times 10^{9}$ cells $/ \mathrm{L}$ after 4 doses). ACT score improved in $6 / 7$ patients $(86 \%)$ (mean pretreatment $10.4 \pm 2.88,13.6 \pm 5.16$ after 4 doses). PAQLQ improved in $4 / 7$ patients $(57 \%$ ) (mean pre-treatment 3.8 $\pm 1.30,4.4 \pm 1.41$ ). We did not demonstrate improvement in $\mathrm{FEV}_{1}$. Mean FeNO was $-15 \pm 29 \mathrm{ppb}$ (figure 1). During treatment, none required hospitalisation for asthma attacks, 2/7 patients (29\%) were attack free, 5/7 patients (71\%) had reduced attack frequency.

Conclusion In adolescents with refractory eosinophilic asthma not eligible for Omalizumab, these data suggest that Mepolizumab is well tolerated, reduces risk of exacerbations, may improve asthma control and quality of life but does not improve lung function.

\section{REFERENCE}

1. Pavord ID, et al. Mepolizumab for severe eosinophilic asthma (DREAM): a multi centre, double-blind, placebo-controlled trial. Lancet 2012;380(9842):651-9.

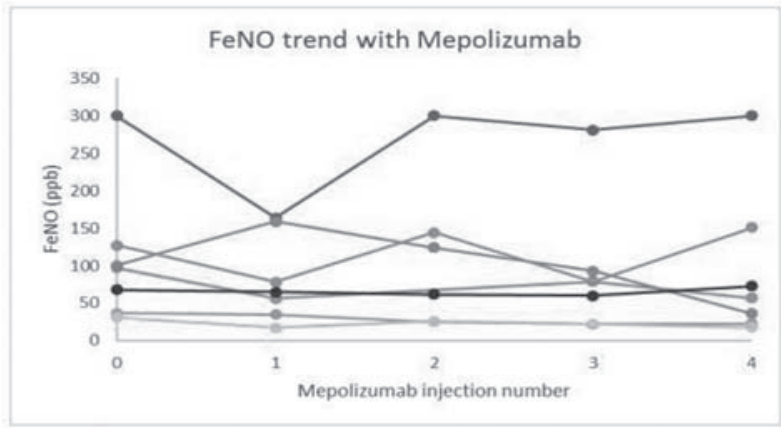

Abstract P71 Figure 1

\section{Pulmonary rehabilitation: walk this way}

\section{P72 IS THE USE OF A NOVEL HIGH FREQUENCY AIRWAY OSCILLATING DEVICE FEASIBLE FOR THE MANAGEMENT OF CHRONIC OBSTRUCTIVE PULMONARY DISEASE?}

E Daynes, TC Harvey-Dunstan, NJ Greening, SJ Singh. Centre of Exercise and Rehabilitation Sciences, Leicester Biomedical Research Centre- Respiratory, Leicester, UK

10.1136/thoraxjnl-2017-210983.214 